1998

\title{
Federal Spending and Economic Growth in Appalachian Counties
}

F Carson Mencken

Follow this and additional works at: https://researchrepository.wvu.edu/rri_pubs

Part of the Regional Economics Commons

\section{Digital Commons Citation}

Mencken, F Carson, "Federal Spending and Economic Growth in Appalachian Counties" (1998). Regional Research Institute Publications and Working Papers. 168.

https://researchrepository.wvu.edu/rri_pubs/168 accepted for inclusion in Regional Research Institute Publications and Working Papers by an authorized administrator of The Research Repository @ WVU. For more information, please contact ian.harmon@mail.wvu.edu. 
Rural Sociology 65(1), 2000, pp. 126-147

Copyright () 2000 by the Rural Sociological Society

\title{
Federal Spending and Economic Growth in Appalachian Counties*
}

\author{
F. Carson Mencken \\ Department of Sociology and Anthropology \\ West Virginia University
}

\begin{abstract}
In this paper I use a model informed by key theories of regional processes, and I test three related hypotheses concerning the effects of different types of federal spending (public investment, defense, salaries/wages) on economic growth in the 399 Appalachian counties during recent business cycles. The analysis incorporates a maximum likelihood estimate spatial lag regression model and shows that federal public investment spending and defense spending exerted net positive effects on per capita income, civilian employment, and private nonfarm employment growth rates between 1983 and 1988. In addition, public investment spending had a positive relationship with percentage of earnings from mining for the 1983-1988 period. Federal spending, however, had less consistent effects during the 1989-1992 recession. Implications for theory and research on regional processes are discussed.
\end{abstract}

In this paper I examine the effects of federal spending on local economic growth in Appalachian counties. Whereas the new ur$\mathrm{ban} /$ rural sociology assumes that the state plays a powerful role in generating regional differences in economic growth, the human ecology perspective downplays the state's role in economic development (Hooks 1994). A rich tradition of research shows that ecological processes are important determinants of social system change and economic growth. I maintain, however, that in a historically lagging economic region such as Appalachia (Couto 1994; Maggard 1994), state involvement, and specifically federal spending, can affect local economic processes net of ecological constructs. This approach to regional processes builds on Hooks's (1994) position that the explanatory powers of competing sociological theories of regional processes (human ecology and the new urban/rural sociology) are relevant to the context in question. An analysis focusing on the relative effects of federal spending will inform both debates on regional processes and future federal budget decisions.

\footnotetext{
* This research was supported by Faculty Senate Research Grant R-97-037 from West Virginia University. I would like to thank the Regional Research Institute at West Virginia University for technical support, and Luc Anselin for access to and advice with SPACESTAT. I would also like to thank Rick Reeder, Mildred Warner, Josh Masnick Kim, Scott Loveridge, Andrew Isserman, and four anonymous reviewers for helpful comments and advice. A previous version of this paper was presented at the annual meetings of the Rural Sociological Society, held in Toronto in August, 1997.
} 
I focus on the 399 counties in Appalachia because this region provides unique opportunities for examining my research question. In 1964 President Lyndon Johnson charged the Appalachian Regional Commission (ARC) with using federal investments to improve socioeconomic conditions in the region. One of the barriers to economic development identified in the original ARC report was the lack of a built environment conducive to economic growth (e.g., roads, water systems, communication technology; see Fuller 1970; PARC 1964). Since 1970, some Appalachian counties have performed at or above national economic growth averages, while many others have lagged behind (Couto 1994). Federal spending (including ARC spending) has not been distributed equally throughout the Appalachian counties (Isserman and Rephann 1995).

In this analysis I examine the extent to which variations in federal spending explain variations in economic performance, in order to inform the theoretical debate in the sociological literature and to provide further insight into the impact of federal efforts in the region.

\section{Literature Review}

The human ecology approach is a market-oriented perspective that focuses on the natural aspects of local development. According to ecological theory, social system growth is partly a function of the spatial dominance of primary sustenance functions (particularly natural resources) and diversity of sustenance activities (Hawley 1986; Hooks 1994; Irwin and Kasarda 1991; Murdock, Hoque, and Backman 1993; Poston 1984). ${ }^{1}$ Spatially dominant systems receive greater resource inputs from external social systems, which increase the complexity of the system and the demand for integrative and coordinative functions (i.e., jobs; Murdock et al. 1993). Human ecology also emphasizes the effects of the built environment (roads, water systems, communication and transportation systems, spatial integration, and economies of scale) on regional processes and the development and retention of spatially dominant sustenance functions, but the connection between the state and the built environment is largely ignored in ecological models (Hooks 1994; Kasarda and Irwin 1991). Hooks (1994:767) claims that ecological theory views state investments in the built environment either as a by-product of private enterprise or as short-term phenomena with little impact. Frisbie and Kasarda (1988:659) conclude that the state's influence on the built environment has been relatively unexplored in ecological models.

Other regional science studies based on a neoclassical perspective also question the economic effectiveness of federal spending.

${ }^{1}$ Murdock et al. (1993) define spatially dominant sustenance functions as those functions (or resources) on which other systems depend for sustenance. 
Many federal spending studies are criticized for being conducted on the wrong level of aggregation and for failing to control adequately for various other place factors that may affect local economic growth (Morgan and LaPlant 1996; Munnell 1990, 1992). Some studies in economics imply that the effects of federal spending are endogenous to the private sector because many federal programs require local matching funds, which are difficult to raise in places that are doing poorly (Benton 1992; Walzer and Deller 1993). Many economists predict that federal spending will exert a negative effect on economic growth (see Cronovich 1997; Kim 1998).

Whereas human ecology sees regional growth as a result of technological innovations and functional imperatives of market adaptations, the new urban/rural sociology assumes that growth coalitions of state, local, and national government leaders and local business elites can forge a "pro-business climate" that keeps profits high, keeps taxes and wages low, and makes places relatively attractive as business locations (Gottdiener and Feagin 1988; D. Smith 1995). Capital accumulation and economic growth are greater in places with pro-business climates, although this growth typically benefits the elite that constitutes the growth coalitions. The new urban/ rural sociology also accepts the state disparity hypothesis: regional differences in federal spending create regional differences in economic growth (Mollenkopf 1983; D. Smith 1995).

Although the new urban/rural sociological research has documented the importance of federal involvement in local economic growth, it focuses on the distribution of federal involvement: Why, for example, do some places receive more than others? How are cutbacks in different urban and rural programs related? Rather than seeking to explain why some Appalachian counties receive more federal spending than others, my research focuses on the economic impact of that spending. A review of the new urban/rural sociology reveals at least three major ways in which federal spending can affect local economic growth: public investment spending, defense and defense contracts, and federal employment.

\section{Federal Public Investment Spending}

According to O'Connor (1973), private capital accumulation and economic growth depend on both physical and human capital (also see Block 1995; Castells 1988; Feagin 1984, 1988; Jaffee 1990). The accumulation of private capital requires public investments in physical infrastructure such as roads, railways, ports, bridges, water/ sewer systems, and hospitals. A well-maintained highway system reduces transportation costs, allowing companies to produce goods at lower cost, increase profits, expand business, hire more workers, and generate more income/employment growth in the local economy (Rephann and Isserman 1995). Munnell $(1990,1992)$ argues 
that a 1 percent increase in public spending on infrastructure increases the output of the national economy by .34 percent. Moreover, Aschauer (1989a, 1989b) shows that public-sector spending increases the gross domestic product (GDP) two to five times more than does private-sector spending. At the local level, public-sector infrastructure spending can improve the business climate, attracting jobs and in-migrants, who fill about half of all new jobs (Munnell 1992; Walzer and Deller 1993). Mehay and Solnick (1990:479) believe that each new in-migrant, in turn, generates 1.259 new jobs through multiplier effects.

O'Connor (1973) also maintains that private capital accumulation depends on mastery of new production processes, educated or skilled workers, cutting-edge materials and products, and advanced technologies. State investment in physical and human capital is necessary because the costs of meeting the physical and human capital needs are too high for private capital. Entrepreneurs will not risk capital in repairing or building roads, highways, and bridges; private corporations cannot assume all the costs of educating workers nor take the financial risks of developing new technologies (Feagin 1984; Hoenack 1993; Jaffee 1990; O'Connor 1973). Therefore the state (particularly the federal government) makes these investments and subsidizes the accumulation of private capital (Feagin 1984, 1988; also see Block 1995 for a review).

This approach to regional growth and development is part of the public goods perspective in economics, and has its foundations in Adam Smith's Wealth of Nations ([1776] 1976). This model, however, has been applied primarily to national economies, with a focus on the impact of public investment on GNP (Kim 1998; Munnell 1992). New urban/rural sociology research suggests that these investments are not distributed equally among places in the U.S. economy, and that places which receive more federal public investment spending also experience greater economic growth (Feagin 1988; Lyson 1989). I maintain that this type of spending is particularly important for lagging regions such as Appalachia because it is necessary to create the built environment and to develop technology and enhance skills necessary for economic growth. Here I test the hypothesis that Appalachian counties which receive more public investment spending experience greater economic growth than other counties in the region.

\section{Federal Defense Spending}

Across disciplines, much attention has been given to the impact of defense spending and to the socioeconomic effects of the emergence of the twentieth-century military-industrial complex (Glickman and Glasmeier 1989; Gottdiener 1994; Markusen 1987; Markusen et al. 1991). Many researchers contend that a shift in fed- 
eral funds to defense spending created regional variation in economic well-being (Falk and Lyson 1993; Johnson et al. 1995; Markusen et al. 1991). A body of research shows that military planning and spending have exerted a major effect on regional and local economic growth beginning in World War II, particularly for the emergence of high-tech engineering and science-based industries in high-tech corridors such as Route 128 in Massachusetts and Silicon Valley and Orange County in California (Hooks 1994; Hooks and Bloomquist 1992; Markusen et al. 1991; Nash 1985). Moreover, Crump (1993; also see Crump and Archer 1993) shows that Department of Defense spending on research and development was a catalyst for the emergence of professional and producer services that acted as contractors or provided support and expertise to defense contractors. This is an important link, given the key role of professional/producer services in generating economic growth in a postindustrial economy (Goe 1994; Sassen 1991).

The effects of defense spending in Appalachia raise an interesting question because, except in some counties, defense spending has not been a major economic force in that region (Couto 1994). In 1983 the median per capita defense spending in Appalachia was only $\$ 28.50$ (in 1993 dollars), but levels of funding were significantly higher in more than 25 percent of Appalachian counties. Past research showed that defense-related spending benefits the places that receive it. Those counties which receive defense spending should benefit thereby and should register significantly higher economic growth rates that do other Appalachian counties. I test this hypothesis in this analysis.

\section{Federal Employment}

Isserman (1994) argues that federal facilities have become cherished prizes in the economic development contest. Federal employment can give communities in lagging regions a competitive advantage throughout the business cycle as a result of higher-wage jobs and greater employment stability. Mollenkopf (1983) states that federal employment is important for two reasons. First, federal civilian layoffs are less prevalent than private-sector layoffs during downturns in the business cycle. Therefore places with a greater proportion of federal employment may perform better than other places during such downturns. Second, places with significant federal employment are marked by more stable employment. Singelmann et al. (1993) believe that this stability translates into consistent local consumption of local goods and services as well as a stable tax base. Local stability, bolstered by federal employment, creates a situation in which long-term local investment in placecompetitive factors (infrastructure, schools) is more feasible; thus 
certain areas may enjoy a competitive advantage in attracting new employment (Hoenack 1993).

Although Kasarda and Irwin (1991) found no support for this argument in a national study, Singelmann et al. (1993) discovered some support in a study of rural economies during the 1980-1982 recession. I maintain that in relation to the other economies in a lagging region, concentration of federal employment can stabilize local economies, lead to economic growth, and guard against economic decline during downturns in the business cycle. I test the hypothesis that differences in federal employment spending cause differences in economic growth in Appalachia.

\section{Independent Variables}

I use an integrated model of regional processes to examine the effects of federal spending on county economic growth in Appalachia during recent business cycles. I frame the analysis to focus on the economic impact of federal spending while controlling for other key determinants of regional processes. I include several key ecological indicators of the built environment, including population density, metropolitan status, and whether the county contains an interstate highway (the two latter variables are binary: $1=$ yes, $0=$ no). Logarithmic first-difference growth rate measures of population change between 1970-1980 and 1980-1990 serve as summary measures of many ecological processes. Previous models (Frisbie and Poston 1976, 1978; Murdock et al. 1993; Poston 1984) show that population change is a function of ecological structure and sustenance organization. My analysis controls for spatial effects (see below), which often indicate spatial diffusion (and economic integration) of economic processes across geographical units of analysis; this is an important construct in human ecology (Kasarda and Irwin 1991).

From the new urban/rural sociology I employ measures of business climate to contrast the effects of federal spending net of business climate measures. Percentage of adult population age 25 or older with some education beyond high school (natural log) serves as a proxy measure of labor-force quality. I also use a measure of manufacturing compensation: compensation per production employee (in dollars), including wages, pensions, and other forms of compensation. In addition, I include a variable for south Appalachia, which serves as a proxy measure for right-to-work status because 90 percent of Appalachian counties in right-to-work states are located in south Appalachia. Others have used these measures as macro-level, critical perspective measures (see Kasarda and Irwin 
1991; Singelmann et al. 1993) because they generally capture a region's business and political climate and are key concepts on the Grant Thornton Index of Business Climate (Isserman 1994:69). I use percentage black of county population (natural log) as a measure of a politically disenfranchised population (Talley and Cotton 1993; Tomaskovic-Devey and Roscigno 1996). Although people tend to regard Appalachia as "white," a portion of the region overlaps with the southern Black Belt; some Appalachian counties are more than 60 percent black. Given the historical importance of southern counties' racial composition for economic growth and development, one must control for this effect in Appalachia. The data on nonfederal spending are taken from USA Counties 1996.

In the analysis I employ three measures of federal spending: defense (including defense procurement and salaries and wages to military and civilian personnel); federal salaries/wages (nondefense); and public investment spending. The last includes research (basic science and engineering, agricultural, forestry, economic and social science, environmental, policy, energy, and university research), infrastructure investment (development grants, airport aid, roads, water systems, loans for infrastructure, rural communication systems, electrification, transportation, and planning grants), and related public goods investments such as school funds, support for vocational education, community development block grants, job training grants, trade promotion grants, business assistance and small business loans, and Appalachian Regional Commission funding. In theory, only public investment, and not public assistance, contributes to private capital accumulation. Therefore I did not include spending on AFDC, SSI, black lung, and childhood immunization. I included several agricultural programs, however, that could be regarded as assistance rather than as investment: rural clean water, forestry research and assistance, and farm operating loans. I compute each of the federal spending measures per capita 1983 and 1989. These per capita measures are skewed right, and I use the natural $\log$ transformations in the analysis. Data are taken from the Consolidated Federal Funds Report (U.S. Bureau of the Census 1994) ..$^{2}$

In the analysis I also control for the effects of dependence on mining (a county's total earnings from this sector as a natural log transformation). I control for mining because growth in mining

\footnotetext{
${ }^{2}$ Some federal spending programs are reported as actual expenditures in a given year, while others are reported as awards granted in a given year, but payment may come in subsequent years (but not reported in those years). One way of assessing the impact of federal spending is to use time lagged growth rates as dependent variables, assuming that the effects of the payments will manifest during the time cycle. An alternative is to use average spending measures for all years in the cycle as a predictor variable. I report the former in the analysis, but also tested the latter with similar results (available upon request).
} 
earnings has differed from national growth rates during several business cycles (Couto 1994; Maggard 1994). The analysis also controls for an interaction effect between federal public investment spending and mining dependence. Previously I showed (Mencken 1996) that mining-dependent counties in Appalachia, primarily in central Appalachia, experienced greater income and employment growth related to aggregate federal spending than did counties in the region that did not depend on mining. Moreover, Fuller (1970) argues that federal public investment aimed at stimulating economic growth in Appalachia should have different effects in counties with greater concentrations of employment in mining because the lack of economic diversification in such counties has created an infrastructure less conducive to economic growth. I control for this potential interaction effect in the analysis.

I also control for percentage of employment in manufacturing. Lyson and Tolbert (1996) show that manufacturing still can play a role in economic development and community well-being in a postindustrial economy. I also attempted to control for age structure and dependence on agriculture/forestry, but all of the measures tested were correlated highly with population change; thus I removed them from the analysis. Independent variables are measured at or near the beginning of the respective business cycles. For the 1983-1988 model, some measures from 1980 must be used (education, population density, percent black) because the variables are not available for noncensus years.

\section{Dependent Variables}

In this analysis I use three dependent variables: per capita income growth, private nonfarm employment growth, and civilian employment growth ("unemployed but looking for work" is adjusted out). I compute the growth rates using the logarithmic first-difference growth rates for the 1983-1988 and 1989-1992 cycles (see Jackman 1980): $\ln \left(T_{2}\right)-\ln \left(T_{1}\right)$. The natural $\log$ transformation of the dependent variable in the year preceding the beginning of the business cycle $(1982,1988)$ is used as the time lag measure in the firstdifference growth rate model. I use a spatial lag regression model to estimate the economic growth rates for the two periods. The coefficients can be interpreted as percentage point changes in the growth rates resulting from unit changes in the independent variables. I use growth rate models (as opposed to a cross-sectional analysis) because, based on previous research, I expect that the effects of federal spending on economic growth will lag by several years (Becker and Lewis 1993; Fuller 1970).

When politically constructed units of analysis such as counties are used in research on economic and social processes, they introduce the potential for spatial autocorrelation among observations. 
A number of options are available to correct for this effect (Land and Deane 1992), but many of these procedures introduce other statistical problems into the analysis (Anselin and Kelejian 1997). I use an MLE spatial lag regression model of the form

$$
y=a+\rho W y+\beta X+\varepsilon
$$

where $\rho W y$ is a spatially lagged dependent variable constructed from $\Sigma_{j} w_{i j} x_{i}$. Anselin (1996) shows that this formula creates a spatial lag for variable $x$ at location $x_{i}$, which is the sum of the product of each county with its corresponding weight from the $i$ th row of the spatial weights matrix $\left(w_{i j}\right)$. As the weighted average of values for all locations, $\rho W y$ allows the dependent variable value in county $x$ to take into consideration the influence of nearby counties. The spatial weights matrix is a measure of distance between each county in the analysis. I employ a squared inverse distance matrix based on a gravity model. Each county's longitude and latitude are used as the distance point references in the analysis; the gravity model, however, places greater emphasis on the values of nearby locations. The spatial lag model is more appropriate for time-series models because in the two-stage least squares approach the spatial effect variable is correlated highly with the time lag (Hooks 1994). I perform the analysis using SPACESTAT, a software package created by Anselin (1995).

\section{Appalachia}

Appalachia, as defined by the Appalachian Regional Commission, consists of 399 counties in 13 states (see Figure 1). More than 20 million people live in the region (Couto 1994). Appalachia is a political construction rather than a closed economic system, even though this analysis treats it as a political entity (Couto 1994; Fuller 1970). I use the 399 counties identified by ARC because ARC funding was included in the public investment spending category, and because inclusion of non-ARC counties in the analysis would have further skewed the distribution of this category.

Economic growth in ARC counties, however, may be spatially dependent on economic growth in neighboring non-ARC counties. To address this issue I created the spatially lagged dependent variables using the 505 counties that are economically integrated into Appalachia (399 ARC counties plus 106 additional counties). I designated the economically integrated counties by using the commuter zones, or patterns of commuting to work between counties, identified by Killian and Tolbert (1993). For all ARC counties I identified the 106 additional non-ARC counties included in their commuter zones. 


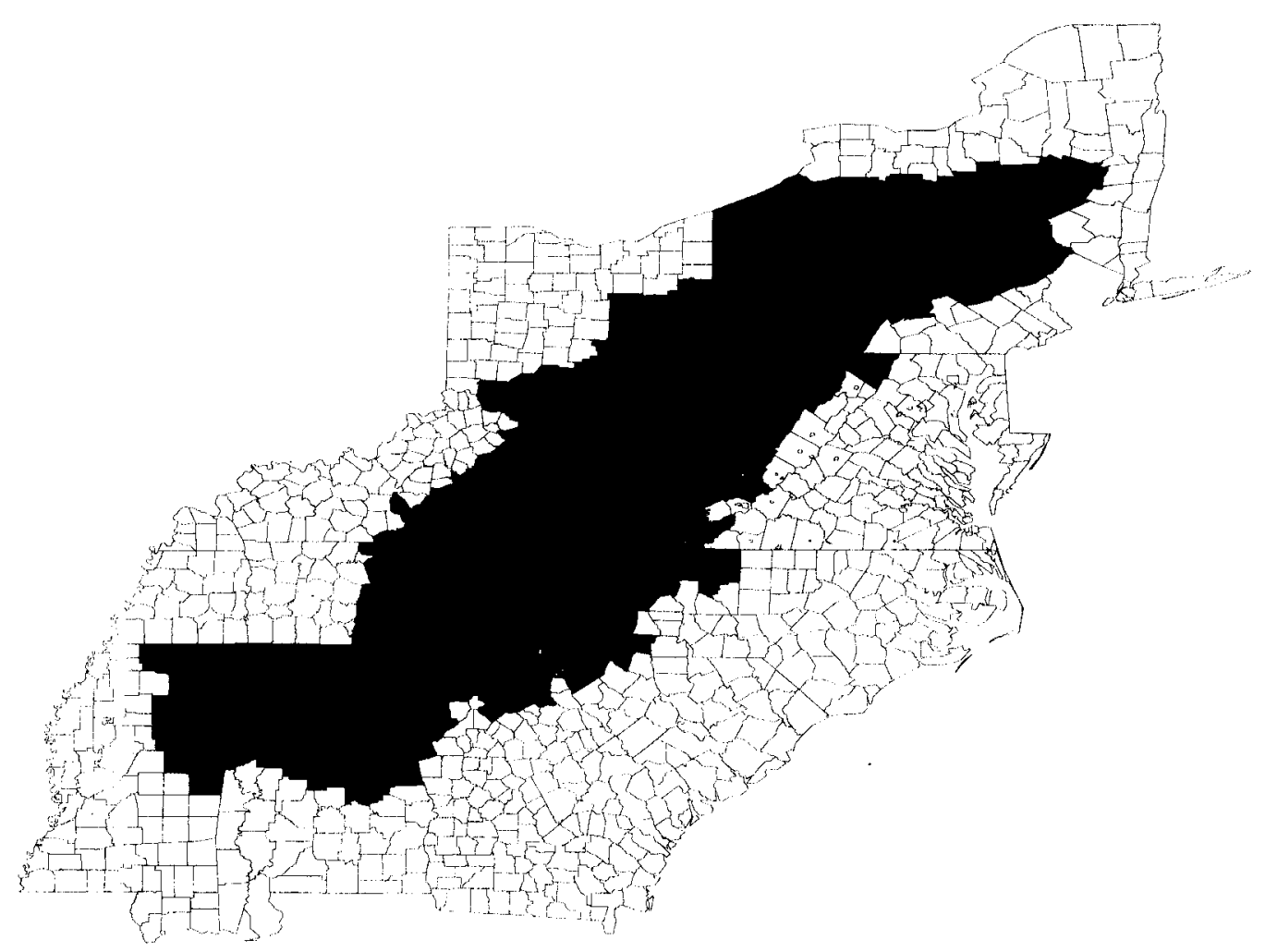

Figure 1. Appalachian Counties

To assess the extent to which omission of these variables created error in the analysis, I attempted to gauge the spatial influence of these non-ARC counties on the economic growth rates in ARC counties. First, I computed the spatially lagged dependent variables for the 505 counties and correlated them with the spatial lags for the 399 counties. If significant spatial association existed between $\mathrm{ARC}$ and non-ARC counties, then these correlations would deviate substantially from 1.00. For each time period, the spatial lag correlations were above .99. That is, the 1983-1988 spatial lag in per capita income for the 399 ARC counties correlated almost perfectly with the 1983-1988 spatial lag in per capita income for the 399 ARC counties plus the 106 integrated counties. In addition, I computed Moran's I spatial association statistics for all dependent variables for the 399 ARC counties and for the 505 ARC counties plus the linked non-ARC counties. These statistics were nearly identical for the two groups; this finding suggests that the 106 non-ARC counties were not interacting substantively with the 399 ARC counties. Finally, I computed local G statistics (Getis and Ord 1992) for the 505 counties to identify the "hot spots" of spatial autocorrelation among the counties in question. Ninety-five percent of the hot spots were located in the ARC region. Counties north of Atlanta, 
however, showed some spatial association for per capita income growth. ${ }^{3}$

\section{Results $^{4}$}

Table 1 presents the spatial lag regression analysis for the 1983-1988 business cycle. The results show consistent support for the hypotheses regarding public investment spending and defense spending. Net of other variables, per capita defense spending had a positive effect on per capita income growth. For each additional percentage point of per capita defense spending, per capita income increased a modest .2 percent. A significant interaction also existed between public investment spending and earnings in mining employment. In counties with no earnings in mining, per capita income growth increased by 1.8 percent for each additional percentage point increase in public investment spending. At a given level of mining earnings, a county that received no public investment spending would show, on average, a predicted -1.5 percent linear relationship between mining and per capita income growth. For each additional percentage point of public investment spending that such a county received, this negative effect would decrease by .1 percent. The impact of public investment federal spending was slightly greater in counties with a greater concentration of earnings in mining. ${ }^{5}$

Many of the other variables exerted significant effects. For each percentage point of population growth between 1970 and 1980, per capita income rose, on average, by .2 percent. The spatial effects coefficient shows strong spatial association in county growth rates in per capita income. Net of these effects, for each additional percentage point of the county population with more than a high school diploma, per capita income grew by 5.5 percent. The percentage of the labor force in manufacturing had a positive effect on the rate of per capita income growth: for each additional per-

\footnotetext{
${ }^{3}$ For this dependent variable the spatial effects may be underestimated. However, a Lagrange Multiplier function, which tests for residual spatial error dependence in spatial lag models, did not detect significant amounts in either the 1983-1988 or the 1989-1992 model; this suggests that not enough residual error was present to affect the quality of the estimates.

${ }^{4}$ I examined the potential for multicollinearity in the final model with zero-order correlations. No zero-order correlation was above .6. I also regressed the independent variables on each other and found no patterns that would suggest problems, according to guidelines used to test for variance inflation.

${ }^{5}$ The statistical significance of the interaction effect was established in the per capita income model with a Lagrange Multiplier function, which showed that including the interaction term significantly improved the fit of the model. The interaction term and the earnings from mining are correlated highly. In addition, if the interaction term is removed, the effects of earnings in mining change appreciably: They are no longer significant. The effects of public investment spending change slightly but are still significant.
} 
Table 1. Spatial Lag Regression Analysis: The Effects of Federal Spending on Economic Growth in Appalachian Counties, 1983-1988 $(N=399)$

\begin{tabular}{|c|c|c|c|}
\hline & $\begin{array}{l}\text { Per Capita } \\
\text { Income } \\
\text { Growth } \\
\text { Coefficient } \\
\end{array}$ & $\begin{array}{c}\text { Civilian } \\
\text { Employment } \\
\text { Growth } \\
\text { Coefficient }\end{array}$ & $\begin{array}{c}\text { Private } \\
\text { Nonfarm } \\
\text { Employment } \\
\text { Growth } \\
\text { Coefficient }\end{array}$ \\
\hline \multicolumn{4}{|l|}{ Federal Spending Measures } \\
\hline Defense 1983 & $.002 *$ & $.01 *$ & $.007 *$ \\
\hline Salary/wg 1983 & -.0007 & -.002 & .001 \\
\hline Public invest. 1983 & $.018^{*}$ & .041 & $.054^{* *}$ \\
\hline \multicolumn{4}{|c|}{ Other New Urban/Rural Sociology Measures } \\
\hline Education 1980 & $.055^{* * *}$ & $.142 *$ & $.096 * * *$ \\
\hline$\%$ black 1980 & -.002 & -.007 & $-.015^{*}$ \\
\hline Manuf. compen. 1983 & $-.0006^{*}$ & .0015 & -.0013 \\
\hline South Appalachia & -.002 & .27 & .002 \\
\hline \multicolumn{4}{|l|}{ Ecological Measures } \\
\hline Interstate & .002 & $.042 *$ & $.047 *$ \\
\hline Pop. density 1980 & .0004 & .0002 & .0001 \\
\hline Pop. change 1970-1980 & $.002 *$ & $.012 * *$ & $.012^{* *}$ \\
\hline Metropolitan co. & .012 & .023 & $.057 * * *$ \\
\hline \multicolumn{4}{|l|}{ Other Measures } \\
\hline Percent in manuf. 1983 & $.027 * * *$ & -.001 & .01 \\
\hline Spatial lag & $.456 * * *$ & $.33 * * *$ & $.44 * * *$ \\
\hline Ern. in mining 1983 & $-.015^{*}$ & $-.038 * *$ & $-.04 * *$ \\
\hline Mining $\times$ pub. invest. & $.001^{\mathrm{a}}$ & $.004^{\mathrm{a}}$ & $.006^{*}$ \\
\hline 1982 lag effect & $-.167 * * *$ & $-.05^{* *}$ & $-.054 * *$ \\
\hline Constant & $1.67 * * *$ & $.4 * * *$ & .37 \\
\hline Model Fit/App. $R^{2}$ & $.49 * * *$ & $.24 * * *$ & $.24 * * *$ \\
\hline
\end{tabular}

a Significance established with Lagrange Multiplier test

$* p<.05 ; * * p<.01 ; * * * p<.001$

Note: Model fit is assessed with a pseudo $r^{2}$ measure, which is the ratio of the variance for predicted values over observed values on the dependent variable.

centage point of the labor force in manufacturing in 1983, per capita income grew by 2.7 percent. Manufacturing compensation, however, exerted a slight negative effect on per capita income growth. The time lag had a net negative effect, indicating regression toward the mean.

The model for the civilian employment growth rates (adjusted for unemployment) shows similar results. Per capita defense spending increased growth in civilian employment by 1.1 percent for each additional percentage point of per capita defense spending. Federal public investment spending had a positive, nonadditive effect on civilian employment growth. In counties with no earnings from mining, for each additional percentage point of per capita 
public investment spending, civilian employment grew by 4.1 percent. In counties that did not receive federal public investment spending in 1983, for each additional 1 percent increase in earnings from mining the civilian employment growth rate is predicted to be 3.8 percent lower. In counties with both earnings from mining and per capita public investment however, for each additional percentage point increase in per capita public investment spending, the negative effect of mining earnings was reduced by .3 percent. Public investment spending exerted a positive effect in all counties, but it was slightly more important for civilian employment growth rates in counties dependent on mining.

Each percentage point increase in population between 1970 and 1980 had a positive effect of 1.2 percent on per capita income growth. We also see a significant amount of spatial association: counties near other counties with higher civilian employment growth rates showed, on average, higher civilian employment growth rates. These positive spatial effects suggest that the economies of Appalachia are integrated across county borders. Net of these effects, counties with better-educated adult populations registered higher civilian employment growth rates between 1983 and 1988. None of the other variables proved statistically significant in this model.

The model for 1983-1988 private nonfarm employment growth shows similar trends. Defense spending exerted a modest effect $(.7$ percent) on growth in private nonfarm employment. Federal public investment spending had a significant nonadditive effect. In nonmining counties, public investment spending increased private nonfarm employment growth by 5.4 percent, on average, for each additional percentage point increase in such spending. The effect of mining concentration on private nonfarm employment depended on the level of federal spending. In counties that received no public investment spending in 1983, each additional percentage point increase in mining earnings predicts, on average, a decline of 4 percent in growth rate. That negative effect, however, was reduced by .6 percent for each percentage point increase in public investment spending received in 1983. In short, public investment spending exerted a positive effect on private nonfarm employment growth, but (as with civilian employment and per capita income) it was slightly more important for counties dependent on mining.

Several other independent variables also affected Appalachian private nonfarm employment growth between 1983 and 1988. Population change between 1970 and 1980 had produced 1.2 percent of growth for each additional percentage point of population. Counties with an interstate highway showed, on average, 4.7 percent higher growth rates in private nonfarm employment; metropolitan counties registered net growth rates 5.7 percent higher than would otherwise have been the case. We also find a significant 
Table 2. Spatial Lag Least Squares Regression Analysis: The Effects of Federal Spending on Economic Growth in Appalachian Counties, 1989-1992 $(N=399)$

\begin{tabular}{lccc}
\hline & $\begin{array}{c}\text { Per Capita } \\
\text { Income } \\
\text { Growth } \\
\text { Coefficient }\end{array}$ & $\begin{array}{c}\text { Civilian } \\
\text { Employment } \\
\text { Growth } \\
\text { Coefficient }\end{array}$ & $\begin{array}{c}\text { Private } \\
\text { Nonfarm } \\
\text { Employment } \\
\text { Growth } \\
\text { Coefficient }\end{array}$ \\
\hline $\begin{array}{l}\text { Federal Spending Measures } \\
\text { Defense 1989 }\end{array}$ & .0003 & .0001 & .002 \\
Salary/wg 1989 & .0008 & -.0005 & .002 \\
Public invest. 1989 & $-.006^{*}$ & $.01^{\mathrm{a}}$ & .001 \\
Other New Urban/Rural Sociology Measures & & & \\
Education 1990 & .01 & -.004 & .009 \\
\% black 1990 & -.001 & -.01 & .005 \\
Manuf. compen. 1989 & .0004 & -.0006 & .0001 \\
South Appalachia & -.004 & .023 & .025 \\
Ecological Measures & & & \\
Interstate & -.002 & -.001 & .003 \\
Pop. density 1990 & $.0004^{* * *}$ & .0005 & .0001 \\
Pop. change 1980-1990 & $-.002^{* *}$ & .001 & .001 \\
Metropolitan co. & .005 & $.047^{* *}$ & $.036^{*}$ \\
Other Measures & & & \\
Percent in manuf. 1989 & -.001 & -.001 & .001 \\
Spatial lag & $.401^{* * *}$ & -.259 & -.15 \\
Ern. in mining 1989 & $.004^{* *}$ & $-.022^{*}$ & .002 \\
Mining $\times$ pub. invest. & $-.001^{*}$ & $.006^{* * *}$ & .00005 \\
1988 lag effect & $-.129^{* * *}$ & -.0001 & $-.035^{*}$ \\
Constant & $1.3^{* * *}$ & $-.053^{*}$ & $.356^{* * *}$ \\
Model Fit/App. $R^{2}$ & $.44^{* * *}$ & $.14^{* * *}$ & $.07^{*}$ \\
\hline & & & \\
\hline$p<.05 ; * * 101 ; * * * p<.001$ & & & \\
\hline
\end{tabular}

${ }^{*} p<.05 ; * * p<.01 ; * * * p<.001$

a Significance established with Lagrange Multiplier test

spatial interaction, suggesting that nonfarm employment growth occurred in county clusters, and that proximity to other counties with higher growth rates in nonfarm employment had a positive effect. Education exerted a positive effect; percent black had a significant negative effect. The time lag shows a negative effect, indicating some regression toward the mean.

The spatial lag least squares results for the 1989-1992 recession are presented in Table 2. These results show that the general model used to explain economic growth among Appalachian counties during the 1983-1988 period does not work well in the 1989-1992 recession: Neither defense spending nor federal salary spending had any effect during the latter period. Public investment spending exerted a significant effect only for civilian employment growth: such 
employment grew by 1.0 percent for each additional percentage point increase in this type of funding in nonmining counties. A modest interaction effect is present: concentration of mining had the predicted negative effect on growth in civilian employment, but for each additional percentage point increase in public investment spending, the negative effect of mining concentration was reduced by .6 percent; the significance of this effect had to be established with a Lagrange Multiplier function test. Public investment spending exerted a net negative effect on per capita income growth during this period, while earnings in mining had a positive effect.

In the 1983-1988 recovery, population change and education had consistent, anticipated effects. This was not the case, however, during the subsequent recession. Metropolitan counties experienced, on average, greater nonfarm and civilian employment growth, and counties with greater population density had slightly higher rates of net per capita income growth. The most reliable predictor of per capita income growth was the spatial effects variable, which showed strong clustering patterns of growth during this period. The negative time lag effects for all dependent variables indicate regression toward the mean, a finding anticipated for a recession. The employment variables (civilian, private nonfarm) lack the spatial association that they showed in the previous cycle. Population change exerted no positive effect during the recession.

\section{Discussion}

Working from the assumption that federal spending is important for economic growth in lagging economic regions, I have tested three hypotheses concerning the impact of federal spending in Appalachia, using an integrated sociological model of regional processes. The analysis finds support in the 1983-1988 business cycle for the two hypotheses on the effects of defense and public investment spending: counties that received more per capita public investment and defense spending experienced, on average, greater income and employment growth between 1983 and 1988. Moreover, the model for growth in private nonfarm employment shows that the economic impact of federal public investment spending extends beyond public-sector growth to influence accumulation of private capital; this outcome is predicted by the new urban/rural sociology. The analysis also supports my basic assumption that federal spending will exert positive effects in a historically lagging economic region.

The analysis shows an expected interaction effect between mining earnings and public investment spending. ${ }^{6}$ Counties with greater

${ }^{6}$ The statistical impact of these interaction effects on economic growth rates during the 1983-1988 recovery, although not statistically impressive at first sight, is not inconsistent with the findings of other researchers (Munnell 1992). Moreover, these interaction effects are "above and beyond" the effects found in nonmining counties. 
earnings from mining experienced slightly higher net income and employment growth related to public investment spending in the 1983-1988 business cycle and slightly higher growth in civilian employment during the 1989-1992 recession. This interaction suggests that the effects of being overdependent on a cyclical niche (such as mining) for sustenance can be meliorated, to some extent, by state action. In those mining counties which did not receive federal public investment spending, income and employment growth rates between 1983 and 1988 were significantly lower than otherwise predicted. The 1983-1988 period was a time of downturn for the coal industry: oil prices declined, and the demand for coal produced energy decreased (Maggard 1994). The negative effects of mining earnings are predicted by human ecology theory: when the niche that sustains a system contracts, the system also will contract. The positive interaction effect, however, suggests that the effects of niche contraction can be meliorated somewhat by state investments; this outcome is predicted by theories that view state involvement as a condition of economic growth.

Some observers argue that the effects of federal spending are endogenous to market forces and other regional processes (such as the built environment and sustenance activity; see Hooks 1994; Walzer and Deller 1993). They point out that many federal programs require matching funds, which are raised more easily in places that are doing well, and argue that any documented net positive effect of federal spending thus would be spurious (Walzer and Deller 1993). Nord and Luloff (1993) observe that mining-dependent counties vary considerably in well-being. Some studies, however (Couto 1994; Mencken 1997), show that throughout the 1980s, levels of well-being were lower, on average, in Appalachian counties that depended more strongly on earnings from mining.

This analysis shows, on average, that the net benefit from public investment spending is greater in counties with greater concentrations of mining earnings, and (by association) in counties that are not doing well. If the effects of federal spending are endogenous to other regional processes, one would anticipate a negative interaction between a federal spending and a county's earnings in mining: that is, spending would have been less beneficial to places with lower levels of well-being. ${ }^{7}$

In this analysis I address a number of criticisms leveled at past studies on federal spending, including arguments that the models

\footnotetext{
${ }^{7}$ Further investigation into the types of specific program spending in these counties for 1983 shows that counties with a greater dependence on mining for employment received significant federal spending for public works and education programs, including assistance in improving water and waste disposal, rural electrification, general public works, assistance in improving existing structures, employment training, education assistance, business development, small business loans, and airport improvement.
} 


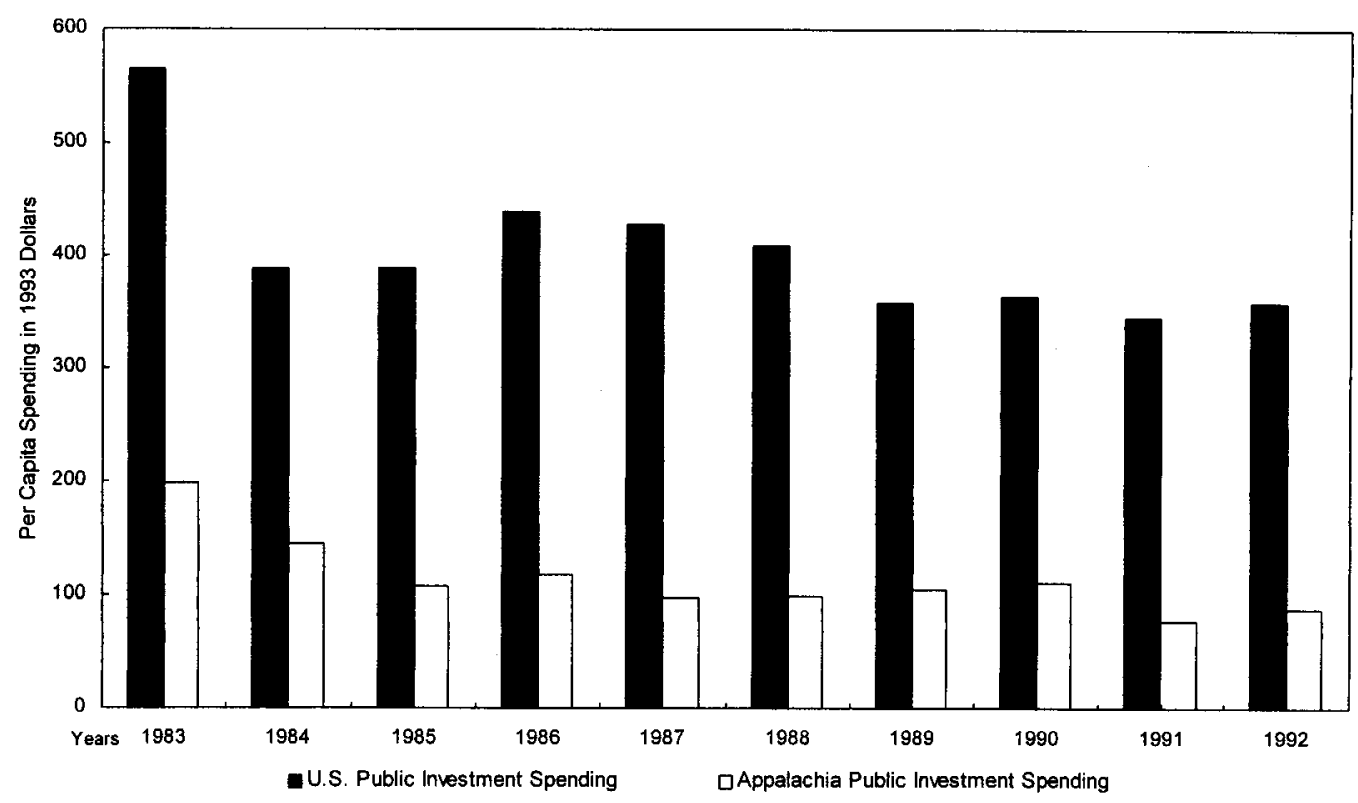

Figure 2. Per Capita Public Investment Spending, U.S. and Appalachia

are too parsimonious, fail to control for spatial diffusion of economic activity across geographical units, or are estimated at a level of aggregation that overstates effects (e.g., Aschauer 1989a, 1989b; Cronovich 1997; Morgan and LaPlant 1996; Munnell 1990, 1992). First, the present analysis incorporates controls from two established theoretical perspectives on regional processes; it demonstrates that net of these controls, federal defense and public investment spending created positive outcomes in the 1983-1988 recovery and exerted a marginal positive effect on growth of civilian employment during the recession.

Second, the spatial lag model controls explicitly for the spatial interaction among counties in the analysis, and the analysis shows that some effects of federal spending persist after spatial diffusion processes have been incorporated into the analysis.

Finally, the effects of public investment spending that others show at the national level (Aschauer 1989a, 1989b) are similar to those which I have documented for the 1983-1988 period with counties (not states or nations) as the unit of analysis. My analysis also shows that defense spending has played some role in shaping the development of the region; this finding is somewhat at odds with the conclusions drawn in other studies of Appalachia (see Couto 1994 for a review).

Two findings are not consistent with my expectations. First, the lack of an effect for federal salary shows that non-defense federal employment is not a major determinant of economic growth in Ap- 
palachia. This implies that federal facilities do not necessarily bring net economic benefits, and that long-term solutions to economic problems in disadvantaged regions will not be solved by an infusion of federal employment opportunities such as federal prisons.

Second, the lack of consistent net effects of federal spending during the 1989-1992 period raises some interesting questions. This finding-that local economies are not affected, during periods of economic contraction, by federal spending in general and by public investment spending in particular-implies that federal spending effects may be inherent in the business cycle. One alternative explanation, however, is that the lack of public investment effects for 1989-1992 is due to the significant reductions in real per capita public investment spending between 1983 and 1989. Falk and Lyson (1993) point out that many federal public investment spending programs were cut during the middle and late 1980s. The time trend for this type of funding, depicted in Figure 2, shows that public investment spending (standardized to 1993 dollars) was reduced 47 percent in real per capita terms between 1983 and 1989 for Appalachian counties; U.S. counties overall experienced a 37 percentage point decrease. (Defense spending in real dollars also was reduced during this period.) If accumulation of private capital is a function of public investment spending, as theory suggests, then real reductions in this spending will cause declines in economic activity. This reduction in federal public investment spending may explain why such spending exerted less consistent effects during the 1989-1992 business cycle.

In this paper I have focused on the impact of federal spending on local economic growth in Appalachia; I have framed the analysis in terms of competing theories of regional processes. The assumption that federal spending affects economic development is grounded in the state disparity hypothesis of the new urban/rural sociology; in this analysis, however, I focused on the effect of federal spending on economic growth. I made no direct attempt here to examine the relationship between federal spending and more traditional outcomes viewed from the critical perspective, such as class divisions and inequality. Growth and development, however, are not the same concepts: places can experience economic growth without economic development (Fuller 1970; Rich 1994; Tolbert, Lyson, and Irwin 1998; Tomaskovic-Devey and Roscigno 1996). Development implies an increase in the well-being of all citizens in local economies, measured by reductions in poverty and income inequality and by increases in real incomes. Growth without development further subdivides populations and increases the socioeconomic gap between groups.

Further analyses focusing on the impact of federal spending on development, as opposed to growth, would allow a more direct 
test of assumptions about the state and economic development in the new urban/rural sociology literature. However, this agenda does not negate the importance of understanding economic growth. The public goods perspective of economic development upon which most development policies are based assumes that growth is a precondition to development (Isserman 1994). Therefore, it is important to understand how social processes, such as federal spending in local economies, affect growth and development.

\section{References}

Anselin, L. 1995. SPACESTAT Version 1.80. Morgantown, WV: Regional Research Institute, West Virginia University.

- 1996. "Simple Diagnostic Tests for Spatial Dependence." Regional Science and Urban Economics 26:77-104.

Anselin, L. and H.H. Kelejian. 1997. "Testing for Spatial Error Autocorrelation in the Presence of Endogenous Regressors." International Regional Science Review 20:153-82.

Aschauer, D.A. 1989a. "Is Public Expenditure Productive?" Journal of Monetary Economics 23:177-200.

- 1989b. "Does Public Capital Crowd Out Private Capital?” Journal of Monetary Economics 24:171-88.

Becker, W.E. and D.R. Lewis. 1993. Higher Education and Economic Growth. Boston: Kluwer.

Benton, J.E. 1992. "The Effects of Changes in Federal Aid on State and Local Government Spending." Publius: The Journal of Federalism 22:71-82.

Block, F. 1995. "The Roles of the State in the Economy." Pp. 691-710 in The Handbook of Economic Sociology, edited by N. Smelser and R. Swedberg. Princeton, NJ: Princeton University Press.

Castells, M. 1988. "High Technology and Urban Dynamics in the United States." Pp. 85-110 in The Metropolis Era. Vol. 1, A World of Giant Cities, edited by M. Dogan and J.D. Kasarda. Beverly Hills: Sage.

Couto, R.A. 1994. An American Challenge. Dubuque: Kendall/Hunt.

Cronovich, R. 1997. "Economic Growth and the Human Capital Intensity of Government Spending." Atlantic Economic Journal 25(3):234-55.

Crump, J.R. 1993. "Sectoral Composition and Spatial Distribution of Department of Defense Services Procurement." The Professional Geographer 45(3):286-96.

Crump, J.R. and J.C. Archer. 1993. "Spatial and Temporal Variability in the Geography of American Defense Outlays." The Political Geographer 12(1):38-63.

Falk, W. and T. Lyson. 1993. "Restructuring Local Labor Markets." Pp. 257-78 in Inequalities in Labor Market Areas, edited by J. Singelmann and F.A. Deseran. Boulder: Westview.

Feagin, J.R. 1984. "The Role of the State in Urban Development: The Case of Houston, TX." Environment and Planning D: Society and Space 2:447-60.

—. 1988. The Free Enterprise City. New Brunswick, NJ: Rutgers University Press.

Frisbie, W.P. and J.D. Kasarda. 1988. "Spatial Processes." Pp. 629-66 in Handbook of Sociology, edited by N.J. Smelser. Beverly Hills: Sage.

Frisbie, W.P. and D.L. Poston. 1976. "The Structure of Sustenance Organization and Population Change in Nonmetropolitan America." Rural Sociology $41: 354-70$. 
1978. "Sustenance Differentiation and Population Redistribution." Social Forces 57:42-56.

Fuller, S.S. 1970. "The Appalachian Experiment." PhD dissertation, Cornell University.

Getis, A. and K. Ord. 1992. "The Analysis of Spatial Association by Use of Distance Statistics." Geographical Analysis 24:189-206.

Glickman, N. and A. Glasmeier. 1989. "The International Economy and the American South." Pp. 60-80 in Deindustrialization and Regional Economic Transformation, edited by L. Rodwin and H. Sazanami. Boston: Unwin Hyman.

Goe, R. 1994. "The Producer Services Sector and Development within the Deindustrializing Urban Community." Social Forces 72:971-1009.

Gottdiener, M. 1994. The Social Production of Urban Space. 2nd ed. Austin: University of Texas Press.

Gottdiener, M. and J. Feagin. 1988. "The Paradigm Shift in Urban Sociology." Urban Affairs Quarterly 24:163-87.

Hawley, A. 1986. Human Ecology: A Theoretical Essay. Chicago: University of Chicago Press.

Hoenack, S. 1993. "Higher Education and Economic Growth." Pp. 21-50 in Higher Education and Economic Growth, edited by W. Becker and D. Lewis. Norwell, MA: Kluwer.

Hooks, G. 1994. "Regional Processes in the Hegemonic Nation: Political, Economic and Military Influences on the Use of Geographic Space." American Sociological Review 59:746-72.

Hooks, G. and L. Bloomquist. 1992. "The Legacy of World War II for Regional Growth and Decline: The Cumulative Effects of Wartime Investments on U.S. Manufacturing, 1947-1972." Social Forces 71:303-37.

Irwin, M.D. and J.D. Kasarda. 1991. "Air Passenger Linkages and Employment Growth in U.S. Metropolitan Areas." American Sociological Review 56:524-37.

Isserman, A. 1994. "State Economic Development Policy and Practice in the United States: A Survey Article." International Regional Science Review 16:49-100.

Isserman, A. and T. Rephann. 1995. "The Economic Effects of the Appalachian Regional Commission." Journal of the American Planning Association 61:345-64.

Jackman, R.W. 1980. "A Note on the Measurement of Growth Rates in Cross-National Research." American Journal of Sociology 86:604-17.

Jaffee, D. 1990. Levels of Socio-Economic Development Theory. New York: Praeger.

Johnson, K.M., J.P. Pelissero, D.B. Holian, and M.T. Maly. 1995. "Local Government Fiscal Burden in Nonmetropolitan America." Rural Sociology 60:381-98.

Kasarda, J.D. and M.D. Irwin. 1991. "National Business Cycles and Community Competition for Jobs." Social Forces 69:733-61.

Killian, M. and C. Tolbert. 1993. "Mapping Social and Economic Space." Pp. 69-82 in Inequalities in Labor Market Areas, edited by J. Singelmann and F.A. Deseran. Boulder: Westview.

Kim, E. 1998. "Economic Gain and Loss from Public Infrastructure Investment." Growth and Change 29:445-68.

Land, K. and G. Deane. 1992. "On the Large-Sample Estimation of Regression Models with Spatial or Network Effects Terms: A Two-Stage Least Squares Approach." Pp. 221-48 in Sociological Methodology, edited by P. Marsden. Cambridge, MA: Blackwell.

Lyson, T. 1989. Two Sides to the Sunbelt: The Growing Divergence between the Rural and Urban South. New York: Praeger. 
Lyson, T. and C. Tolbert Jr. 1996. "Small Manufacturing and Civic Welfare in the U.S. Nonmetropolitan Counties: A Regional Comparison." Environment and Planning $A$ 28:1779-94.

Maggard, S.W. 1994. "From Farm to Coal Camp to Back Office and McDonald's: Living in the Midst of Appalachia's Latest Transformation." Journal of the Appalachian Studies Association 6:14-38.

Markusen, A. 1987. Regions: The Economics and Politics of Territory. Totowa, NJ: Rowan and Littlefield.

Markusen, A., P. Hall, S. Campbell, and S. Deitrick. 1991. The Rise of the Gunbelt: The Military Remapping of Industrial America. New York: Oxford University Press.

Mehay, S. and L. Solnick. 1990. "Defense Spending and State Economies." Journal of Regional Science 4:477-87.

Mencken, F.C. 1996. "Income and Employment Change in Appalachia during the 1983-88 Business Cycle Recovery: Locating Differential Effects in North, Central and South Appalachia." Journal of Appalachian Studies 2(1):77-86

—_. 1997. "Regional Differences in Socioeconomic Well-Being in Appalachia during the 1980s." Sociological Focus 30:79-97.

Mollenkopf, J.H. 1983. The Contested City. Princeton, NJ: Princeton University Press.

Morgan, D.R. and J.T. LaPlant. 1996. "Federal Spending across States: An Analysis of Recent Trends." Social Science Quarterly 77:315-28.

Munnell, A.H. 1990. "Why Has Productivity Growth Declined? Productivity and Public Investment." New England Economic Review “ (January/February):3-22.

- 1992. "Policy Watch: Infrastructure Investment and Economic Growth." Journal of Economic Perspectives 6:189-98.

Murdock, S.H., M.N. Hoque, and K. Backman. 1993. "Determinants of 1980-1990 Net Migration in Texas Counties." Rural Sociology 58:190-209.

Nash, G.D. 1985. The American West Transformed. Bloomington: Indiana University Press.

Nord, M. and A. Luloff. 1993. "Socioeconomic Heterogeneity of Mining-Dependent Counties." Rural Sociology 58:492-500.

O'Connor, J. 1973. The Fiscal Crises of the State. New York: St. Martin's.

President's Appalachian Regional Commission (PARC). 1964. Appalachia: A Report by the President's Appalachian Regional Commission. Washington, DC: U.S. Government Printing Office.

Poston, D.L. 1984. "Regional Ecology: A Macroscopic Analysis of Sustenance Organization." Pp. 323-82 in Sociological Human Ecology, edited by M. Micklin and H. Choldin. Boulder: Westview.

Rephann, T. and A. Isserman. 1995. "New Highways as Economic Development Tools." Regional Science and Urban Economics 24:723-51.

Rich, D.Z. 1994. The Economic Theory of Growth and Development. Westport, CT: Praeger.

Sassen, S. 1991. The Global City: New York, London, Tokyo. Princeton, NJ: Princeton University Press.

Singelmann, J., F.A. Deseran, F.C. Mencken, and J.H. Li. 1993. "What Drives Labor Market Growth?” Pp. 125-42 in Inequalities in Labor Market Areas, edited by J. Singelmann and F.A. Deseran. Boulder: Westview.

Smith, Adam. [1776] 1976. An Inquiry into the Nature and Causes of the Wealth of Nations. Oxford: Clarendon.

Smith, D.A. 1995. "The New Urban Sociology Meets the Old: Rereading Some Classical Human Ecology." Urban Affairs Review 30:432-57. 
Talley, C. and B. Cotton. 1993. "Minority Concentration and Black-White Inequality in U.S. Labor Market Areas." Pp. 237-56 in Inequalities in Labor Market Areas, edited by J. Singelmann and F.A. Deseran. Boulder: Westview.

Tolbert, C.M., T.A. Lyson, and M.D. Irwin. 1998. "Local Capitalism, Civic Engagement, and Socioeconomic Well-Being." Social Forces 77:401-28.

Tomaskovic-Devey, D. and V.J. Roscigno. 1996. "Racial Economic Subordination and White Gain in the U.S. South." American Sociological Review 61:565-89.

U.S. Bureau of the Census. 1996. USA Counties 1996 on CD-ROM [machine-readable data files]. U.S. Bureau of the Census[producer and distributor].

U.S. Bureau of the Census. 1994. Consolidated Federal Funds Report 1983-92 on CDROM [machine-readable data files]. U.S. Bureau of the Census [producer and distributor].

Walzer, N. and S.C. Deller. 1993. "Federal Aid and Rural County Highway Spending: A Review of the 1980s." Policy Studies Journal 21 (2):309-24. 